\title{
Ar insultą patyrusių pacientų kognityvinės funkcijos siejasi su depresiškumu ir saviveiksmingumu?
}

\author{
J. Janavičiūtė \\ L. Šinkariova \\ Vytauto Didžiojo universitetas
}

\begin{abstract}
Santrauka. İvadas. Galvos smegenų insultas yra dažna mirties priežastis visame pasaulyje, o mirtingumo rodiklius padidina po insulto atsiradę kognityvinių funkcijų sutrikimai ir pasireiškiantis depresiškumas. Nèra aišku, kodèl vieniems pacientams pasireiškia depresijos simptomai ir kognityvinių funkcijų sutrikimai, o kitiems - ne. Didesnis saviveiksmingumas yra siejamas su mažesniu depresiškumu, geresne gyvenimo kokybe ir kasdieniu funkcionavimu, tačiau nėra aišku, kaip insultą patyrusių pacientų saviveiksmingumas yra susijęs su kognityvinių funkcijų raiška ir depresiškumu. Todèl svarbu tyrinèti šių trijų reiškinių sąsajas, siekiant atskleisti saviveiksmingumo reiškinį, apsaugantį nuo kognityvinių funkcijų prastėjimo ir depresijos išsivystymo.

Tyrimo tikslas - įvertinti insultą patyrusių pacientų kognityvinių funkcijų sąsajas su depresiškumu ir saviveiksmingumu.

Tiriamieji ir tyrimo metodai. Tiriamiesiems buvo pateikti socialiniai ir demografiniai klausimai. Insultą patyrusiụ pacientų kognityvinès funkcijos buvo matuotos Adenbruko kognityvinio tyrimo III versija. Depresiškumui išmatuoti buvo naudotas Paciento sveikatos klausimynas, saviveiksmingumui - Saviveiksmingumo klausimynas insultą patyrusiems pacientams. Siekiant nustatyti smegenų pusrutulio pažeidimą po ịvykusio insulto, buvo naudotas piršto bakstelëjimų neuropsichologinis instrumentas.

Rezultatai ir išvados. Tyrimo rezultatai atskleidè, kad insultą patyrusių pacientu kognityvinių funkcijų pablogèjimas nèra susijęs su padidẻjusiu depresiškumu ar sumažėjusiu saviveiksmingumu bendroje insultą patyrusių pacientų grupeje. Insultą patyrusių pacientų grupejje, kurie pasižymi geresnėmis kognityvinėmis funkcijomis, geresnès dėmesio funkcijos yra susijusios su mažesniu depresiškumu ir didesniu saviveiksmingumu. Toje pacientų grupëje blogesnès kalbos funkcijos yra susijusios su didesniu bendru saviveiksmingumu ir didesniais šio konstrukto aktyvumo poskalès rezultatais; geresni erdviniai gebẻjimai taip pat susiję su didesniais savikontrolès poskalès įverčiais. Nepriklausomai nuo kognityvinių funkcijų raiškos, geresni insultą patyrusių pacientų erdviniai gebèjimai yra susiję su didesniu bendru saviveiksmingumu.
\end{abstract}

Raktažodžiai: insultą patyrę pacientai, kognityvinès funkcijos, saviveiksmingumas, depresiškumas.

\section{IVADAS}

Galvos smegenų insultas yra dažna mirties priežastis visame pasaulyje. Europoje insultas yra laikomas viena dažniausių mirtį sukeliančių priežasčių [1]. Didžioji dalis iš-

\author{
Adresas: \\ Jovita Janavičiūtè \\ Vytauto Didžiojo universitetas, Socialinių mokslu fakultetas, \\ Psichologijos katedra \\ Jonavos g. 66, LT-44138 Kaunas \\ El.paštas janaviciute.jovita@gmail.com
}

gyvenusių insultą patiria insulto sukeltas pasekmes, kurios paveikia kasdienį žmogaus funkcionavimą, sukeldamos kognityvinio funkcionavimo ir emocinès būsenos sutrikimus, kurie susiję ir su mažesniu tokių asmenų saviveiksmingumu [2].

Net trečdalis insultą išgyvenusių pacientų patiria depresijos simptomus [3], o kognityvinių funkcijų sutrikimus patiria nuo 35 iki $87 \%$ pacientų [4]. Pacientų, kuriems pasireiškia poinsultinè depresija, insulto pažeistos funkcijos atsistato sunkiau, jų gyvenimo kokybė yra blogesnè, o mirtingumas - didesnis [5]. Teigiama, kad poinsultinė depresija ir kognityvinių funkcijų pablogejjimas yra susiję reiški-

(C) Neurologijos seminarai, 2020. Open Access. This article is distributed under the terms of the Creative Commons Attribution 4.0 International License CC-BY 4.0 (http://creativecommons.org/licenses/by/4.0/), which permits unrestricted use, distribution, and reproduction in any medium, provided you give appropriate credit to the original author(s) and the source, provide a link to the Creative Commons license, and indicate if changes were made. 
niai. Vis dèlto nèra pakankamai aišku, ar poinsultinè depresija daro įtaką kognityvinėms funkcijoms ar atvirkščiai, o kai kuriais atvejais teigiama, kad tai - nesusiję reiškiniai. Vieni autoriai [6] įrodo ryšį tarp kognityvinių funkcijų sutrikimų ir poinsultinès depresijos, kiti mokslininkai šio ryšio nenustato $[7,8]$. Tokie nevienareikšmiški rezultatai skatina ir toliau tyrinèti kognityvinių funkcijų ir depresiškumo ryšį insultą patyrusių pacientų imtyje.

Taip pat šioje tyrinèjimo srityje nèra atsakyta ị klausimą, kodèl vieniems pacientams pasireiškia poinsultinė depresija ir kognityvinių funkcijų sutrikimai, o kitiems ne. Siekiant geriau suprasti insultą patyrusių pacientų kognityvinių funkcijų ir depresijos ryši, svarbu ieškoti kitų psichologinių veiksnių, paveikiančių šias sąsajas tiesiogiai arba per jų tarpusavio sąveikas. Šios žinios pasitarnautų organizuojant reabilitacijos procesą specifiškai insultą patyrusiems pacientams. Vienas iš svarbių psichologinių veiksnių, kuris daro didelę įtaką insultą patyrusių pacientu reabilitacijos procesui, yra saviveiksmingumas. Didesnis insultą patyrusių pacientų saviveiksmingumas yra siejamas su mažesniu depresiškumu, geresne gyvenimo kokybe, fiziniu ir kasdieniu funkcionavimu [9, 10]. Mažesnis saviveiksmingumas yra glaudžiai susijęs su blogesnèmis kognityvinėmis funkcijomis, nes žmonès su kognityvinių funkcijų sutrikimais turi mažiau kognityvinių išteklių apdoroti teigiamus aplinkos stimulus, kurie galètų paskatinti teigiamus įsitikinimus dèl savo galimybių ịveikti tam tikrus sunkumus [11].

Analizuojant mokslinę literatūrą, aptikta, kad tyrimų, nagrinėjančių insultą patyrusių pacientų kognityvinių funkcijų, depresiškumo ir saviveiksmingumo ypatumus bei kognityvinių funkcijų sąsajas su depresiškumu ir saviveiksmingumu, yra mažai, todèl jie išlieka aktualūs. Apžvelgti tyrimai rodo, kad insultą patyrusių pacientų saviveiksmingumas ar jo ryšys su kognityvinemis funkcijomis ir depresiškumu nėra pakankamai ištyrinètas. Taigi, šis tyrimas prisideda prie geresnio insultą patyrusių pacientų ryšio tarp jų kognityvinių funkcijų ir depresiškumo bei saviveiksmingumo supratimo. Jo naujumą sudaro tai, kad tyrime būtų naudojami specializuoti instrumentai, skirti insultą patyrusiems pacientams.

\section{DARBO TIKSLAS}

İvertinti insultą patyrusių pacientų kognityvinių funkcijų sąsajas su depresiškumu ir saviveiksmingumu.

\section{TIRIAMIEJI IR TYRIMO METODAI}

Tyrimui atlikti gautas Psichologo profesinès etikos komisijos leidimas (Nr. EKL-2020.01). Prieš atliekant tyrimą, visi tiriamieji pasiraše informuoto sutikimo formą. Tyrimas buvo pradetas $2020 \mathrm{~m}$. kovo 9 d. ir sustabdytas kovo 16 d. dèl šalyje ịvesto karantino, susijusio su COVID-19 paplitimu. Tyrimas atliktas Kauno klinikinès ligoninès
Fizinès medicinos ir reabilitacijos II bei Geriatrijos skyriuose. Anoniminė tiriamųju apklausa buvo vykdyta tiesiogiai tyrejui fiksuojant atsakymo rezultatus apklausos protokole. Kiekvieno tyrimo dalyvio apklausa užtruko apie 1 val.

Tyrime dalyvavo 22 insultą patyrę pacientai. Nors mūsų tyrimo imtis nėra didelè, tačiau pasaulinè praktika rodo, kad tyrimai su insultą patyrusiais pacientais atliekami taip pat nedidelèse klinikinèse imtyse $[12,13]$.

İtraukimo kriterijai:

1) patyrè galvos smegenų insultą per pastaruosius 6 mènesius;

2) gimtoji kalba - lietuvių;

3) praejjo ne mažiau kaip 1 sav. nuo atvykimo ị Fizinès medicinos ir reabilitacijos II skyrių;

4) praejjo ne mažiau kaip 2 dienos nuo atvykimo ị Geriatrijos skyrių;

5) MMSE - didesnis nei 15 balų.

Neįtraukimo (atmetimo) kriterijai:

Tiriamieji nebuvo kviečiami dalyvauti tyrime, jeigu po ívykusio insulto pasireiškẻ sunkūs motoriniai sutrikimai (pvz., apraksija, rankų parezè), afazija ar kiti neuropsichologiniai sutrikimai, kurie galètų turèti įtakos tyrimo rezultatams.

\section{Instrumentai (skalès)}

Apklausa pradèta nuo socialinių ir demografinių charakteristikų anketos, kurioje pacientai nurodè savo lyti, amžių, gyvenamają vietą, išsilavinimą, šeiminę padètį. Kognityvinès tiriamujų funkcijos ịvertintos naudojant Adenbruko kognityvinio tyrimo III versiją (angl. Addenbrooke's Cognitive Examination, ACE-III) [14]. Atliekant ši testą, daugiausia galima surinkti 100 balų. Kuo daugiau surenkama balų, tuo geresnès asmens pažintinès funkcijos. Šiuo instrumentu yra tiriamos penkios sritys: demesys, atmintis, kalbos sklandumas, kalba, erdviniai gebejjimai. Šis instrumentas yra nemokamas ir laisvai prieinamas, jo atlikimas užtrunka apie 15 minučių. Testas pasižymi aukštu jautrumu ir specifiškumu, gerais psichometriniais rodikliais. Taip pat ACE-III pasižymi aukštu vidiniu suderinamumu (Chronbach $\alpha=0,88$ ) [15]. Insultą patyrusių pacientų imtyje siūlomas ribinis balas yra 82 [16]. Vilniaus universiteto Taikomosios psichologijos laboratorija šị instrumentą yra išvertusi ị lietuvių kalbą, gautas jos leidimas jị naudoti. Šiame darbe instrumentas pasižymi aukštu vidiniu suderinamumu (Chronbach $\alpha=0,84$ ).

Tiriamujų depresiškumas buvo įvertintas naudojant Paciento sveikatos klausimyną (angl. Patient Health Questionnaire, PHQ-9) [17]. PHQ-9 yra išverstas i lietuvių kalbą, nemokamas ir laisvai prieinamas svetainėje www.phqscreeners.com. Tiriamieji, surinkę nuo 0 iki 4 balų, nepasižymi arba pasižymi minimaliu depresiškumu, surinkę 5-9 balus - nedideliu depresiškumu, 10-14 vidutiniu depresiškumu, 15-19 - vidutiniškai sunkiu depresiškumu, o surinkę daugiau nei 20 balų pasižymi sunkiu depresiškumu. Šiame darbe instrumentas pasižymi aukštu vidiniu suderinamumu (Chronbach $\alpha=0,75$ ). 
Tyrimo dalyvių saviveiksmingumas buvo išmatuotas naudojant Saviveiksmingumo klausimyną insultą patyrusiems pacientams (angl. The Stroke Self-Efficacy Questionnaire, SSEQ) [18]. SSEQ sudaro 13 teiginių, kurie yra specifiniai šios pacientų grupės saviveiksmingumui išmatuoti ir apima jų kasdienio funkcionavimo veiklas. Ši skalè pasižymi gerais psichometriniais rodikliais [18, 19]. Klausimynas tiria dvi insultą patyrusių pacientų saviveiksmingumo sritis [20]: aktyvumą ir savikontrolę. Šis klausimynas yra laisvai prieinamas ir nemokamas, o jị išversti į lietuvių kalbą ir naudoti buvo gautas autorių leidimas. Šiame darbe instrumentas pasižymi aukštu vidiniu suderinamumu (Chronbach $\alpha=0,83$ ).

Siekiant nustatyti dèl ịvykusio insulto preliminariai pažeistą smegenų pusrutulị, tyrime buvo naudotas Piršto bakstelėjimų testas (angl. Finger tapping test, FTT) [21]. FTT pasižymi gerais psichometriniais rodikliais ir yra dažnai naudojamas insultą patyrusių pacientų imtyse [22-24]. Šiame darbe instrumentas pasižymi aukštu vidiniu suderinamumu (Chronbach $\alpha=0,97-0,98)$.

\section{Statistinis duomenų apdorojimas}

Visų duomenų normalumas buvo patikrintas naudojant Kolmogorovo-Smirnovo ir Šapiro-Vilk kriterijus. Atsižvelgiant ị mažą tiriamujų imtị, siekiant nustatyti skirtumus skirtingose socialinių ir demografinių bei klinikinių rodikliu grupėse buvo naudoti neparametriniai MannWhitney U ir Kruskal-Wallis kriterijai. Siekiant nustatyti ryšius, jų stiprumą ir statistinị reikšmingumą, buvo naudotas neparametrinis Spirmeno koreliacijos koeficientas. Rezultatai laikyti statistiškai reikšmingais, kai $\mathrm{p}<0,05$.

Tyrimo rezultatų analizè ir statistiniai skaičiavimai atlikti naudojant IBM SPSS programos 21 versiją (angl. Statistical Package for the Social Sciences).

\section{REZULTATAI}

Tyrime dalyvavo 22 insultą patyrę asmenys. Tiriamųjų amžius svyravo nuo 61 iki 89 metų, amžiaus vidurkis buvo $78,09 \pm 8,6 \mathrm{~m}$. Tyrime dalyvavo 11 vyrų ir 11 moterų. $77 \%$ tiriamujų buvo gyvenantys mieste, o $23 \%$ - kaime. Tiriamieji pagal išsilavinimą buvo suskirstyti ị dvi grupes: turinčius vidurinị ir žemesnį nei vidurinị išsilavinimą (64 \%) ir turinčius aukštesnị nei vidurinị išsilavinimą (36 \%) tiriamuosius. Beveik pusė (45 \%) tiriamųjų buvo susituokę, $41 \%$ - našliai, o $14 \%$ - išsiskyrę. $50 \%$ tiriamųjų buvo priskirti kairiojo pusrutulio insulto grupei, $41 \%$ - dešiniojo pusrutulio insulto grupei, o $9 \%$ buvo nediferencijuoti pagal insulto lokalizaciją.

Rezultatai atskleidè, kad tiriamieji, kurie turèjo aukštesnị nei vidurinị išsilavinimą, pasižymėjo geresniais kalbos ir bendrų kognityvinių funkcijų (ACE-III) ịverčiais, lyginant su vidurinị ir žemesnį nei vidurinị išsilavinimą turinčiais tiriamaisiais $(\mathrm{p}<0,05)$. Siekiant eliminuoti išsilavinimo ịtaką, šis kintamasis buvo perskaičiuotas ị intervalinị kintamajị ir, siekiant nustatyti depresiškumo bei savi- veiksmingumo ryšį su kalbos ir bendromis kognityvinėmis funkcijomis, buvo naudotas dalinis koreliacijos koeficientas, kontroliuojant išsilavinimo ịtaką rezultatams.

Tyrimo rezultatai atskleidè, kad kognityvinès funkcijos ir atskiri jų rodikliai (dèmesys, atmintis, verbalinis sklandumas, kalba, erdviniai gebejimai) nėra statistiškai reikšmingai $(p>0,05)$ susiję su depresiškumu bendroje insultą patyrusių pacientų imtyje.

Siekiant geriau suprasti insultą patyrusių pacientų kognityvinių funkcijų ir atskirų jų rodiklių (dèmesio, atminties, verbalinio sklandumo, kalbos, erdvinių gebėjimų) ir depresiškumo ryši, tiriamieji buvo padalinti ì dvi lygias grupes $(\mathrm{N}=11)$ pagal bendrą ACE-III ịverčio vidurkị (vidurkis - 68 balai). Pirmają grupę sudarè tiriamieji su prastesnemis kognityvinėmis funkcijomis (surinko mažiau nei 68 ACE-III balus), antrają - su geresnèmis kognityvinèmis funkcijomis (surinko 68 ACE-III balus ir daugiau).

Analizuojant kognityvinių funkcijų ir atskirų jų rodiklių ryši su depresiškumu insultą patyrusių pacientų, pasižyminčių prastesnėmis kognityvinėmis funkcijomis, grupejje rezultatai taip pat atskleidè, kad kognityvinès funkcijos ir atskiri jų rodikliai statistiškai reikšmingai nėra susiję ( $p>0,05)$ su depresiškumu. Atitinkama analizè atlikta su insultą patyrusių pacientų, pasižyminčių geresnemmis kognityvinėmis funkcijomis, grupe. Šių tiriamųjų grupejje nustatytas neigiamas stiprus statistiškai reikšmingas $(\mathrm{r}=-0,79, \mathrm{p}<0,01)$ ryšys tarp dèmesio funkcijos ir depresiškumo. Tai reiškia, kad didesnis dėmesingumas yra susijęs su mažesniu depresiškumu ir, priešingai, didesnis depresiškumas - su mažesniu dėmesingumu.

Apibendrinant minètus rezultatus, galima teigti, kad kognityvinès funkcijos ir atskiri jų rodikliai nèra susiję su depresiškumu bendroje imtyje ir insultą patyrusių pacientų, pasižyminčių prastesnėmis kognityvinèmis funkcijomis, grupejje. Tiriamujų, pasižyminčių geresnemmis kognityvinėmis funkcijomis, grupejje yra rastas stiprus, neigiamas ir statistiškai reikšmingas ryšys tarp dèmesingumo ir depresiškumo.

Analizuojant insultą patyrusių pacientų kognityvinių funkcijų ir atskirų jų rodiklių ryši su saviveiksmingumu, rezultatai atskleidžia, kad saviveiksmingumas statistiškai reikšmingai nėra susijęs su kognityvinėmis funkcijomis ir atskirais jų rodikliais bendroje insultą patyrusių pacientų imtyje (1 lentelè).

Siekiant išsamiau analizuoti insultą patyrusių pacientų kognityvinių funkcijų ir jų atskirų rodiklių bei saviveiksmingumo ryšį, tiriamieji buvo padalinti į dvi anksčiau aprašytas prastesnių ir geresnių kognityvinių funkcijų grupes. Rezultatai atskleidè, kad prastesnių kognityvinių funkcijų pacientų grupejje nustatytas stiprus neigiamas statistiškai reikšmingas $(\mathrm{p}<0,05)$ ryšys tarp erdvinių gebejjimų ir pacientų saviveiksmingumo (2 lentelè). Tai reiškia, kad prastesnių kognityvinių funkcijų pacientams geresni erdviniai gebėjimai yra susiję su didesniu saviveiksmingumu.

Atitinkama analizė atliekama su insultą patyrusiais pacientais, pasižyminčiais geresnèmis kognityvinėmis funkcijomis. Rezultatai atskleidžia, kad šioje tiriamųjų grupejje tarp dèmesio ir bendro saviveiksmingumo yra nustatytas 
1 lentelè. Kognityvinių funkcijų ir atskirų jų rodiklių ryšys su saviveiksmingumu

\begin{tabular}{||l|c|c|c||}
\hline Kintamasis & $\begin{array}{c}\text { Aktyvumo } \\
\text { subskalė (r) }\end{array}$ & $\begin{array}{c}\text { Savikontrolés } \\
\text { subskalè (r) }\end{array}$ & $\begin{array}{c}\text { Bendras saviveiks- } \\
\text { mingumo ịvertis (r) }\end{array}$ \\
\hline Dėmesys & 0,111 & 0,09 & 0,327 \\
\hline Atmintis & $-0,036$ & 0,037 & 0,032 \\
\hline Verbalinis sklandumas & $-0,049$ & $-0,244$ & $-0,093$ \\
\hline Kalba & 0,091 & $-0,192$ & $-0,031$ \\
\hline Erdviniai gebejjimai & 0,277 & 0,365 & 0,387 \\
\hline Bendros kognityvinės funkcijos (ACE-III suminis įvertis) & 0,107 & 0,156 & 0,129 \\
\hline
\end{tabular}

${ }^{*} \mathrm{p}<0,05, * * \mathrm{p}<0,01, * * * \mathrm{p}<0,001$

2 lentelè. Insultą patyrusių pacientų, pasižyminčių prastesnėmis kognityvinėmis funkcijomis, kognityvinių funkcijų ir atskirų jų rodiklių ryšys su saviveiksmingumu

\begin{tabular}{||l|c|c|c||}
\hline Kintamasis & $\begin{array}{c}\text { Aktyvumo } \\
\text { subskalė (r) }\end{array}$ & $\begin{array}{c}\text { Savikontrolés } \\
\text { subskalè (r) }\end{array}$ & $\begin{array}{c}\text { Bendras saviveiks- } \\
\text { mingumo îvertis (r) }\end{array}$ \\
\hline Dėmesys & $-0,165$ & $-0,419$ & $-0,089$ \\
\hline Atmintis & $-0,167$ & 0,005 & $-0,041$ \\
\hline Verbalinis sklandumas & 0,162 & $-0,217$ & $-0,061$ \\
\hline Kalba & 0,357 & $-0,216$ & 0,192 \\
\hline Erdviniai gebejjimai & $\mathbf{0 , 8 5 1 * *}$ & 0,233 & 0,398 \\
\hline Bendros kognityvinės funkcijos (ACE-III suminis įvertis) & 0,332 & $-0,131$ & 0,250 \\
\hline
\end{tabular}

$* \mathrm{p}<0,05, * * \mathrm{p}<0,01, * * * \mathrm{p}<0,001$

3 lentelè. Insultą patyrusių pacientų, pasižyminčių geresnėmis kognityvinėmis funkcijomis, kognityvinių funkcijų ir atskirų jų rodiklių ryšys su saviveiksmingumu

\begin{tabular}{||l|c|c|c||}
\hline \hline Kintamasis & $\begin{array}{c}\text { Aktyvumo } \\
\text { subskalė (r) }\end{array}$ & $\begin{array}{c}\text { Savikontrolės } \\
\text { subskalė (r) }\end{array}$ & $\begin{array}{c}\text { Bendras saviveiks- } \\
\text { mingumo įvertis (r) }\end{array}$ \\
\hline Dėmesys & 0,376 & 0,518 & $\mathbf{0 , 7 4 2 * *}$ \\
\hline Atmintis & 0,21 & 0,294 & 0,363 \\
\hline Verbalinis sklandumas & $-0,696$ & $-0,246$ & $-0,016$ \\
\hline Kalba & $\mathbf{- 0 , 9 4 3 * *}$ & $-0,522$ & $\mathbf{- 0 , 9 4 1}^{* *}$ \\
\hline Erdviniai gebejjimai & $-0,35$ & $\mathbf{0 , 6 2 5}$ & $\mathbf{0 , 6 6 5 ^ { * }}$ \\
\hline Bendros kognityvinès funkcijos (ACE-III suminis įvertis) & $-0,64$ & $-0,076$ & $-0,504$ \\
\hline
\end{tabular}

${ }^{*} \mathrm{p}<0,05, * * \mathrm{p}<0,01, * * * \mathrm{p}<0,001$

stiprus, teigiamas ir statistiškai reikšmingas $(\mathrm{p}<0,05)$ ryšys. Taip pat nustatytas vidutiniškas, teigiamas ir statistiškai reikšmingas $(p<0,05)$ ryšys tarp erdviniu gebėjimu ir saviveiksmingumo savikontrolès poskalès bei bendro saviveiksmingumo ịverčio. Tai reiškia, kad tiriamųjų, pasižyminčių geresnėmis kognityvinėmis funkcijomis, grupèje geresnès dèmesingumo funkcijos yra susijusios su aukštesniu saviveiksmingumu, o aukštesni erdvinių gebėjimu rodikliai - su aukštesniu saviveiksmingumu, atliekant savikontrolès reikalaujančias užduotis. Geresni erdviniai gebẻjimai yra statistiškai reikšmingai susiję su geresniu saviveiksmingumu abiejose kognityvinių funkcijų grupėse. Taip pat gauti rezultatai atskleidžia, kad tarp kalbos ir aktyvumo subskalès bei bendro saviveiksmingumo yra rastas stiprus, neigiamas ir statistiškai reikšmingas $(p<0,05)$ ryšys. Tai reiškia, kad geresnės kalbos funkcijos yra susijusios su mažesniu saviveiksmingumu insultą patyrusių pacientų, pasižyminčių geresnėmis kognityvinėmis funkcijomis, grupèje (3 lentelè).

\section{REZULTATU APTARIMAS}

Šiame tyrime buvo siekiama įvertinti kognityvinių funkcijų sąsajas su depresiškumu ir saviveiksmingumu.

Tyrimo rezultatai atskleide, kad bendroje šiame tyrime surinktoje insultą patyrusių pacientų imtyje ir geresnèmis kognityvinėmis funkcijomis pasižyminčių pacientų grupėje didesnis depresiškumas nebuvo susijęs su prastesnemmis pažintinėmis funkcijomis. Šie rezultatai nesutampa su dalies mokslininku gaunamais rezultatais, kad po insulto atsiradusi depresija yra susijusi su prastesnemis kognityvinėmis funkcijomis [5, 25-27]. Kiti autoriai nustato, kad po insulto išsivysčiusi depresija gali būti ankstyva demencijos stadija, kuriai besivystant trinka kognityvinès funkcijos [28]. Taigi galima manyti, kad depresija išsivysto anksčiau nei žymūs kognityvinių funkcijų sutrikimai. Kita vertus, šiame tyrime gauti rezultatai sutampa su kai kurių mokslininkų gaunamais rezultatais, kurie neranda ryšio tarp poinsultinès depresijos ir kognityvinių funkcijų pa- 
blogèjimo [29]. Taip pat kai kurie tyrëjai [30] teigia, kad po insulto atsiradusios depresijos išsivystymas yra ne iki galo aiškus ir skiriasi nuo ịprastos depresijos, todèl kognityvinès funkcijos nebūtinai gali būti susijusios su didesniu depresiškumu. Reikètų neatmesti galimybès, kad tokie rezultatai gali būti gauti dèl to, jog šiame darbe pacientai nebuvo diferencijuoti pagal trukmę, praejusią nuo patirto insulto, ir nebuvo renkama informacija apie prieš insultą turètus nuotaikos sutrikimus, kurie galëjo paveikti rezultatus. Taip pat šiame darbe gauti rezultatai prieštarauja mokslininkų keliamoms prielaidoms apie depresiškumo ir kognityvinių funkcijų ryšį bei mechanizmą [31], todèl galima manyti, kad po insulto atsiradusios depresijos išsivystymo mechanizmas yra kiek kitoks nei iprastos depresijos, nes, kaip minèta, ryšio tarp kognityvinių funkcijų ir depresiškumo neranda ir kiti mokslininkai.

Tyrimo rezultatai atskleidè, kad insultą patyrusių pacientų, pasižyminčių geresnėmis kognityvinėmis funkcijomis, prastesnès dėmesio funkcijos yra susijusios su didesniu depresiškumu. Panašius rezultatus randa ir kiti autoriai [32], kad mažesnis demesingumas yra susijęs su aukštesniu depresiškumu, bet ne su kitais kognityvinių funkcijų rodikliais. Visgi ryšys, randamas tarp prastesnių dẻmesio funkcijų ir didesnio depresiškumo, gali būti susijęs su tuo, kad beveik visiems insultą patyrusiems pacientams yra aptinkamas pablogèjęs dèmesys [33]. Dėmesio funkcijos pablogèjimas yra labai svarbus, nes susijęs su daugeliu kasdienybejje atliekamų veiklų ir yra siejamas su judèjimo sunkumais, blogesnèmis ligos pasekmèmis [34]. Siekiant suprasti, kodèl ryšys buvo gautas tik tų insultą patyrusių pacientų, kurie pasižymėjo geresnèmis kognityvinėmis funkcijomis, grupeje, verta atkreipti dèmesį, kad geresnėmis kognityvinèmis funkcijomis pasižymintys pacientai yra kritiškesni savo būklei ir turi daugiau kognityvinių išteklių, kurie leistų suprasti pablogèjusio dèmesingumo pasekmes tolimesniam funkcionavimui.

Taip pat tyrimo rezultatai atskleide, kad insultą patyrusių pacientų prastesnės kognityvinės funkcijos nèra susijusios su mažesniu saviveiksmingumu bendroje šio tyrimo imtyje. Panašius rezultatus gauna ir kiti tyrèjai, kurių rezultatai atskleidžia, kad saviveiksmingumas nèra susijęs su kognityvinėmis funkcijomis, tačiau abu šie veiksniai prognozuoja sẻkmingus vyresnio amžiaus žmonių apsipirkinèjimo gebėjimus [35]. Taip pat, analizuojant socialinèje kognityvineje teorijoje keliamas prielaidas, galima pastebèti, kad tyrime gauti rezultatai joms prieštarauja. Socialinejje kognityvinèje teorijoje teigiama, kad pasižymintiems prastesnėmis kognityvinėmis funkcijomis būdinga mažiau optimistiškų ịsitikinimų apie save, kadangi jie neturi pakankamai kognityvinių išteklių, todèl neatkreipia dèmesio i pozityvius aplinkos stimulus, kurie formuotu teigiamus ịsitikinimus apie save [11]. Visgi, atsižvelgiant ị minètas prielaidas, galima manyti, kad asmenys turètų pasižymèti žemesniais kognityvinių funkcijų rodikliais nei daugelis šiame tyrime dalyvavusių tiriamųjų, jog nesuvoktų pozityvių išorinių stimulų. Taip pat šiame tyrime buvo matuotas specifinis saviveiksmingumas insultą patyrusiems pacientams, tačiau ị tyrimą buvo kviečiami pakankamai pajègūs pacientai, todèl galimai jų saviveiksmingumas buvo didesnis ir sąsajos tarp kognityvinių funkcijų ir saviveiksmingumo nebuvo atrastos. Tokius rezultatus galëjo paveikti ir tai, kad buvo naudojama specifiška insultą patyrusiems pacientams saviveiksmingumą matuojanti skalè, kurios teiginiuose nurodytos veiklos geresnès būklès tiriamiesiems galẻjo atrodyti lengvai ịgyvendinamos.

Tiriamuosius suskirsčius ị dvi grupes pagal gaunamus kognityvinių funkcijų įverčius, atskirose tiriamujų grupèse buvo rasti ryšiai taip atskirų kognityvinių funkcijų rodiklių ir atskirų saviveiksmingumo poskalių. Rezultatai atskleidè, kad abiejose grupèse geresni erdviniai gebėjimai yra susiję su didesniu saviveiksmingumu. Šie rezultatai turi svarų paaiškinimą - asmenys su geresniais erdviniais gebejjimais yra linkę patirti mažiau traumų, kritimų ir yra savarankiškesni [36]. Taip pat, tiriamieji, atlikdami ACE-III užduotis, skirtas įvertinti erdvinius gebëjimus, turëjo ne tik suvokti pateiktą vaizdinę informaciją, bet ir nubraižyti ịvairias figūras, todèl geresni rezultatai gali būti susiję su geresne jų fizine būkle. Tai reikštų, kad jie gali gana sèkmingai atlikti užduotis, kuriose reikalinga atlikti tikslius rankų judesius. Tokie judesiai yra būtini ir kasdienėje veikloje, o sėkmingai atliekamos užduotys siejamos su aukštesniu saviveiksmingumu [11]. Tyrimo rezultatai atskleidè, kad geresnèmis kognityvinèmis funkcijomis pasižyminčių tiriamujjų grupejje geresnès dèmesio funkcijos yra susijusios su didesniu saviveiksmingumu. Tokie rezultatai patvirtina socialinės kognityvinès teorijos keliamą prielaidą, kad geresnèmis kognityvinėmis funkcijomis pasižymintys tiriamieji daugiau demesio skiria teigiamiems aplinkos stimulams, formuojantiems pozityvesnị savęs vaizdą [11]. Toje pačioje tiriamujų grupẻje buvo gauti rezultatai, kurie atskleidè, kad prastesnès kalbos funkcijos yra susijusios su aukštesniais saviveiksmingumo aktyvumo subskalès ir bendrais saviveiksmingumo rezultatais. Tokie rezultatai gali būti gauti dèl to, kad tiriamieji, kurių kalba yra prastesnè, nebūtinai prasčiau atlieka SSEQ skalëje nurodytas veiklas, kurios labiau atspindi gebejjimus fiziškai atlikti kasdienes veiklas, bet neapima socialinių aspektų. Taigi, nors tiriamujjų kalba ir buvo sutrikusi, tai neatspindi jų fizinių gebėjimų, kurie reikalingi sẻkmingai atlikti kasdienes užduotis. Interpretuojant tokius rezultatus iš kitos perspektyvos, geresnès kalbos funkcijos gali būti susijusios su žemesniu saviveiksmingumu, kas rodytų, jog pacientai turi pakankamai kognityvinių išteklių kritiškai vertinti po insulto atsiradusius sunkumus, o tai lemia mažesnị saviveiksmingumą. Panašius ar prieštaringus rezultatus gaunančių mokslininkų rasti nepavyko.

Apibendrinant reikètų atkreipti dèmesį, kad šiame tyrime gauti rezultatai turètų būti vertinami atsargiai, dèl egzistuojančiu ribotumų. Vienas iš pagrindinių ribotumų yra maža tiriamųjų imtis, kadangi dèl šalyje susiklosčiusios situacijos nebuvo surinkta planuota tiriamuju imtis. Dèl mažo tiriamųjų skaičiaus galèjo atsirasti netikètai aukštas, neigiamas, statistiškai reikšmingas koreliacijos koeficientas tarp kalbos ir saviveiksmingumo. Atsižvelgiant ị șị ribotumą, nerekomenduojama apibendrinti rezultatų visai insultą patyrusių pacientų grupei. Taip pat vie- 
nam iš ribotumų galima priskirti insulto lokalizacijos nustatymą. Šiame tyrime insulto lokalizacija buvo nustatoma ne objektyviu metodu - Piršto bakstelejjimų testu, todèl tiriamieji galèjo būti suskirstyti ị grupes ne visai tiksliai.

Tokio pobūdžio tyrimai ateityje išlieka aktualūs su didesne tiriamujjų imtimi. Didesnè tiriamųjų imtis būtų naudinga atskleidžiant subtilesnius ryšius tarp insultą patyrusių pacientų kognityvinių funkcijų, depresiškumo ir saviveiksmingumo. Be viso to, ateities tyrimuose būtų pravartu naudoti ne tik specifišką insultui saviveiksmingumą matuojantị klausimyną, bet ir bendrą saviveiksmingumą matuojančią skalę, siekiant atsakyti ị klausimą, kuris iš minètų geriau atskleidžia insultą patyrusių pacientų saviveiksmingumo, depresiškumo ir kognityvinių funkcijų sąsajas. Siekiant tiksliau atskleisti insulto lokalizacijos reikšmę kognityvinių funkcijų, depresiškumo ir saviveiksmingumo ryšiui, ateities tyrimuose būtų naudinga įtraukti insulto lokalizaciją, kuri fiksuojama smegenovaizdžio tyrimais.

\section{IŠVADOS}

1. Bendroje insultą patyrusių pacientų grupeje didesnis depresiškumas nėra susijęs su mažesniu saviveiksmingumu.

a. Insultą patyrusių pacientų, kurie pasižymi geresnèmis kognityvinèmis funkcijomis, grupèje geresnès dẻmesio funkcijos yra susijusios su žemesniu depresiškumu.

2. Bendroje insultą patyrusių pacientų grupejje blogesnès kognityvinès funkcijos nèra susijusios su didesniu depresiškumu.

a. Insultą patyrusių pacientų, kurie pasižymi prastesnèmis kognityvinėmis funkcijomis, grupejje geresni erdviniai gebejjimai yra susiję su didesniu saviveiksmingumu.

b. Insultą patyrusių pacientų, kurie pasižymi geresnèmis kognityvinėmis funkcijomis, grupejje geresnès dèmesio funkcijos yra susijusios su didesniu saviveiksmingumu.

c. Insultą patyrusių pacientų, kurie pasižymi geresnèmis kognityvinėmis funkcijomis, grupėje blogesnès kalbos funkcijos yra susijusios su didesniais saviveiksmingumo aktyvumo subskalès ir bendros saviveiksmingumo skalès rezultatais.

d. Insultą patyrusių pacientų, kurie pasižymi geresnèmis kognityvinėmis funkcijomis, grupèje geresni erdviniai gebejjimai yra susiję su didesniais saviveiksmingumo savikontrolès subskalès ir bendros saviveiksmingumo skalès rezultatais.

\section{FINANSAVIMAS}

Tyrimas finansuotas projekto „Insultą patyrusių pacientų kognityvinio funkcionavimo ir emocinès būsenos sąsajos “ (Nr. 09.3.3-LMT-K-712-16-0051), kuris vykdomas pagal LMT poveiklę „Studentų gebejjimų ugdymas vykdant tyrimus semestro metu“, lëšomis.

\section{Literatūra}

1. European Commission. State of Health in the EU. Lithuania. Country Health Profile 2017. OECD and World Health Organization, 2017.

2. Lewin A, Jöbges M, Werheid K. The influence of self-efficacy, pre-stroke depression and perceived social support on self-reported depressive symptoms during stroke rehabilitation. Neuropsychol Rehabil 2013; 23(4): 546-62. https://doi.org/10.1080/09602011.2013.794742

3. Hackett ML, Pickles K. Part I: frequency of depression after stroke: an updated systematic review and meta-analysis of observational studies. Int J Stroke 2014; 9(8): 1017-25. https://doi.org/10.1111/ijs.12357

4. Terroni L, Sobreiro MF, Conforto AB, et al. Association among depression, cognitive impairment and executive dysfunction after stroke. Dement Neuropsychol 2012; 6(3): 152-7. https://doi.org/10.1590/S198057642012DN06030007

5. Kutlubaev MA, Hackett ML. Part II: predictors of depression after stroke and impact of depression on stroke outcome: an updated systematic review of observational studies. Int $\mathbf{J}$ Stroke 2014; 9(8): 1026-36. https://doi.org/10.1111/ ijs. 12356

6. Murata Y, Kimura M, Robinson RG. Does cognitive impairment cause poststroke depression? Am J Geriatr Psychiatry 2000; 8(4): 310-7. https://doi.org/10.1097/00019442200011000-00007

7. Gillen R, Tennen H, McKee TE, Gernert-Dott P, Affleck G. Depressive symptoms and history of depression predict rehabilitation efficiency in stroke patients. Arch Phys Med Rehabil 2001; 82(12): 1645-9. https://doi.org/10.1053/ apmr.2001.26249

8. Morrison V, Pollard B, Johnston M, MacWalter R. Anxiety and depression 3 years following stroke: demographic, clinical, and psychological predictors. J Psychosom Res 2005; 59(4): 209-13. https://doi.org/10.1016/j.jpsychores. 2005.02.019

9. Jones F, Riazi A. Self-efficacy and self-management after stroke: a systematic review. Disabil Rehabil 2011; 33(10): 797-810. https://doi.org/10.3109/09638288. 2010.511415

10. Korpershoek C, Van der Bijl J, Hafsteinsdóttir TB. Self-efficacy and its influence on recovery of patients with stroke: a systematic review. J Adv Nurs 2011; 67(9): 1876-94. https://doi.org/10.1111/j.1365-2648.2011.05659.x

11. Bandura A. Exercise of personal and collective efficacy in changing societies. In: Bandura A, ed. Self-efficacy in changing societies. Cambridge University Press, 1995; 1-45. https://doi.org/10.1017/CBO9780511527692.003

12. Alexandrova ML, Danovska MP. Cognitive impairment one year after ischemic stroke: predictorsand dynamics of significant determinants. Turk J Med Sci 2016; 46(5): 1366-73. https://doi.org/10.3906/sag-1403-29

13. French MA, Moore MF, Pohlig R, Reisman D. Self-efficacy mediates the relationship between balance/walking performance, activity, and participation after stroke. Top Stroke Rehabil 2016; 23(2): 77-83. https://doi.org/10.1080/ 10749357.2015.1110306

14. Hsieh S, Schubert S, Hoon C, Mioshi E, Hodges JR. Validation of the Addenbrooke's Cognitive Examination III in frontotemporal dementia and Alzheimer's disease. Dement Geriatr Cogn Disord 2013; 36(3-4): 242-50. https://doi.org/ $10.1159 / 000351671$ 
15. Noone P. Addenbrooke's cognitive examination-III. Occup Med 2015; 65(5): 418-20. https://doi.org/10.1093/occmed/ kqv041

16. Lees R, Selvarajah J, Fenton C, et al. Test accuracy of cognitive screening tests for diagnosis of dementia and multidomain cognitive impairment in stroke. Stroke 2014; 45(10): 3008-18. https://doi.org/10.1161/STROKEAHA. 114.005842

17. Kroenke K, Spitzer RL. The PHQ-9: a new depression diagnostic and severity measure. Psychiatr Ann 2002; 32(9): 509-15. https://doi.org/10.3928/0048-571320020901-06

18. Jones F, Partridge C, Reid F. The Stroke Self-Efficacy Questionnaire: measuring individual confidence in functional performance after stroke. J Clin Nur 2008; 17(7b): 244-52. https://doi.org/10.1111/j.1365-2702.2008.02333.x

19. Topçu S, Oğuz S. Translation and validation study for the stroke self-efficacy questionnaire in stroke survivors. Int J Nurs Pract 2018; 24(4): e12646. https://doi.org/10.1111/ijn.12646

20. Riazi A, Aspden T, Jones F. Stroke Self-efficacy Questionnaire: a Rasch-refined measure of confidence post stroke. J Rehabil Med 2014; 46(5): 406-12. https://doi.org/10.2340/ 16501977-1789

21. Reitan RM. Manual for administration of neuropsychological test batteries for adults and children. Neuropsychology Laboratory: Indiana University Medical Center, 1959.

22. Strauss E, Sherman EM, Spreen O. A compendium of neuropsychological tests: administration, norms, and commentary. American Chemical Society, 2006.

23. de Groot-Driessen D, van de Sande P, van Heugten C. Speed of finger tapping as a predictor of functional outcome after unilateral stroke. Arch Phys Med Rehabil 2006; 87(1): 40-4. https://doi.org/10.1016/j.apmr.2005.09.022

24. Stoodley CJ, MacMore JP, Makris N, Sherman JC, Schmahmann JD. Location of lesion determines motor vs. cognitive consequences in patients with cerebellar stroke. NeuroImage: Clinical 2016; 12: 765-75. https://doi.org/ 10.1016/j.nicl.2016.10.013

25. Robinson RG, Jorge RE. Post-stroke depression: a review. Am J Psychiatry 2015; 173(3): 221-31. https://doi.org/ 10.1176/appi.ajp.2015.15030363

26. Van Mierlo ML, Van Heugten CM, Post MW, De Kort PL, Visser-Meily JM. Psychological factors determine depressive symptomatology after stroke. Arch Phys Med Rehabil 2015; 96(6): 1064-70. https://doi.org/10.1016/j.apmr. 2015.01.022

27. Tu J, Wang LX, Wen HF, Xu YC, Wang PF. The association of different types of cerebral infarction with post-stroke depression and cognitive impairment. Medicine 2018; 97(23): e10919. https://doi.org/10.1097/MD. 0000000000010919

28. Panza F, Frisardi V, Capurso C, et al. Late-life depression, mild cognitive impairment, and dementia: possible continuum? Am J Geriatr Psychiatry 2010; 18(2): 98-116. https://doi.org/10.1097/JGP.0b013e3181b0fa13

29. Baccaro A, Wang YP, Candido M, et al. Post-stroke depression and cognitive impairment: study design and preliminary findings in a Brazilian prospective stroke cohort (EMMA study). J Affect Disord 2019; 245: 72-81. https://doi.org/ 10.1016/j.jad.2018.10.003

30. Villa RF, Ferrari F, Moretti A. Post-stroke depression: mechanisms and pharmacological treatment. Pharmacol Ther 2018; 184: 131-44. https://doi.org/10.1016/j.pharmthera. 2017.11.005
31. Weisenbach SL, Boore LA, Kales HC. Depression and cognitive impairment in older adults. Curr Psychiatry Rep 2012; 14(4): 280-8. https://doi.org/10.1007/s11920-012-0278-7

32. Hosking SG, Marsh NV, Friedman PJ. Depression at 3 months poststroke in the elderly: predictors and indicators of prevalence. Aging Neuropsychol Cogn 2000; 7(4): 205-16. https://doi.org/10.1076/anec.7.4.205.798

33. Stapleton T, Ashburn A, Stack E. A pilot study of attention deficits, balance control and falls in the subacute stage following stroke. Clin Rehabil 2001; 15(4): 437-44. https://doi.org/10.1191/026921501678310243

34. McDowd JM, Filion DL, Pohl PS, Richards LG, Stiers W. Attentional abilities and functional outcomes following stroke. J Gerontol B Psychol Sci Soc Sci 2003; 58(1): P45-53. https://doi.org/10.1093/geronb/58.1.P45

35. Helmes E, Klinger J. Prediction of everyday task performance in older adults by perceived health, self-efficacy and cognitive ability. Cogent Psychol 2017; 4(1): 1297281. https://doi.org/10.1080/23311908.2017.1297281

36. Chan KS, Fong KNK. Accidental falls among community-dwelling people with chronic stroke in Hong Kong. Asian J Gerontol Geriatr 2013; 8(2): 61-7.

\section{J. Janavičiūtė, L. Šinkariova}

\section{ARE COGNITIVE FUNCTIONS ASSOCIATED WITH DEPRESSION AND SELF-EFFICACY IN STROKE PATIENTS?}

\section{Summary}

Background. Stroke is a common cause of death worldwide. Post stroke cognitive impairment and depression increase mortality rates and complicate recovery. It is not clear why some patients experience post stroke depression and cognitive impairment and others do not. Meanwhile, higher self-efficacy is associated with lower depression, better quality of life, and daily functioning in a sample of stroke patients, so it is important to examine the links between these three phenomena.

The aim of the study was to investigate the relationships between cognitive function, depression, and self-efficacy in stroke patients.

Materials and methods. The subjects were asked socio-demographic questions. Cognitive function in stroke patients was measured using Addenbrooke's Cognitive Examination III. The Patient Health Questionnaire was used to measure depression, and The Stroke Self-Efficacy Questionnaire was used for self-efficacy. Finger tapping test was used in the study to determine the location of the stroke.

Results and conclusions. The results of the study reveal that cognitive function in stroke patients is not associated with depression or self-efficacy in the general group of stroke patients. In the group of stroke patients with better cognitive function, better attentional function is associated with lower depression and higher self-efficacy. In the same group, poorer language functions are associated with higher scores on the self-efficacy activity subscale and overall self-efficacy scale results. As well as, better spatial abilities are associated with higher scores on the self-efficacy self-management subscale and overall self-efficacy scale results. In the group of stroke patients with poorer cognitive function, better spatial ability is associated with higher self-efficacy.

Keywords: stroke patients, cognitive function, self-efficacy, depression.

Gauta:

20200618

Priimta spaudai: 20200824 